\title{
RYODORAKU-THERAPY OF EPILEPSY
}

\author{
-with special reference to E. E. G.-
}

Masuto Misawa M. D., Ph. D.

Director of the Japanese Ryodoraku Autonomic Nervous System Association and Vice-Director of Shironishi Hospital

脳波は脳髄の自発性電気変動を誘発用電極を探索する頭皮に接着し、それを紙面に記録した あのであるが、その脳波上の特に異常波の部位に刺針し、通電するととにより䋃発生電流より 強い電流刺激を加えるととになり波形の変化（好転）をきたすととができたので報告する。

\section{Introduction}

Electroencephalography is the technique of recording and interpreting the spontaneous electrical activity of the brain in the form of electrical potentials by applying electrodes the scalp (1), and is widely used for diagnostic purposes and drug effect evaluation.

The electroencephalograms of almost all the patients with "epilepsy" in particular show pathologic waves of the brain. In some patients such pathologic waves can be improved by surgical or medicinal treatment. In the maiority of patients with epilepsy, however, the pathologic waves stubbornly resist all treatments, surgical and medicinal, so that it is quite difficult to cure those patients.

The treatment of "epilepsy", especially needle treatment, has long been practiced in China, and many physicians including Nakatani have obtained a good therapeutic effect by electric needle treatment (Ryodoraku autonomic nervous system treatment). The author has obtained a relatively good result by the use of a method of treatment which differs from the needle treatment practiced in China and electric needle treatment used by Nakatani. This paper lescribes the results obtained by the author.

\section{Materials and Method}

The apparatus used in this experiment was a needle electrode low-frequency neuro meter and the so-called needle anesthetic machine.

When the presence of pathologic brain waves was confirmed by the electroencephalogram, and needles were placed at the sites of the scalp where pathologic waves were obtained by the electrodes, and a current of 8 volts, $10 \mu \mathrm{A}$ was applied for 20 minutes.

\section{Therapeutic effect Evaluation}

The subjects who had convalsions and showed pathologic waves in every EEG despite the continued medicinal treatment were selected, and their EEGs were compared before and after treatment or before and several days after treatment to evaluate the treatment effects. 


\section{Case Report}

Case A : 25-year-old female

This patient had convulsions (typical) from her childhood and was treated with antiepilectics for a long time, but still had 1 to 7 episodes of convulsion every month, and her EEG showed no improvement. Other clinical examination and tests were not remarkable. When the patient was placed on this treatment, the EEG began to improve rapidly and on the tenth day of treatment the EEG showed entirely different brain waves than those recorded before treatment. At this stage of treatment, the patient was completely freed of all symptoms, both subjective and objective.

Case B : 22-year-old female

Convulsions came on at the age of 3 to 4 , and the patient was treated with antiepileptics till she was 22 years old. In spite of the continued medicinal treatment, she still had 1 to 11 episodes of convulsion every month, and the EEGs showed 3-4 per second slow waves and occasional spikes with some irreqularuty. Immediately after the onset of treatment, almost normal brain waves were restored, with the amplitude of slow waves being reduced. She has had no attack of convulsion since the onset of treatment.

Case C : 40-year-old male

Seven years ago, the patient fell from a high place and sustained head confusion. He was admitted to and discharged from several hospitals and visited other hospitals as well for a work-up, and the tests (cerebral angiography, x-ray examination, echo test, etc.) revealed no remarkable findings. However, the EEGs showed pathologic waves, and the patient had convulsions and compained of headache, a sensation of heaviness in the head and hemiparesthesia. Two years passed but all these symptoms persisted. When the patient was placed on this treatment, all the complaints disappeared immediately, and convulsions no more came on. He has since then returned to work and been healthy.

\section{Conclusion}

"Epilepsy" has been treated by needle therapy in China of old, and Nakatani et al, have been treated it with electric needle therapy for quite some time. The author developed a new meedle therapy which somewhat differs from the methods above. The author's method consists in placing needles at the sites of the scalp where the EEG shows pathologic waves and applying an electrical current.

In other words, this method is a reversal of the process from brain wave generation to its recording. The therapeutic effect of this treatment seems to be derived from the fact that when an electric stimulus stronger than the electric potentials originating from the scalp is applied to the brain and its nerve cells, the spontaneous electrical activity of the sites of stimulation undergoes a local change. Not only during electrical stimulation but also after removal of the needles, the stimulus remains effective, thus helping restore normal brain waves. In this treatment, needles are also placed at the "Gokoku" with electrical stimulation. 


\section{Reference}

1) Wada, T. : Clin., EEG, P. 38, 1957, Kanehara Shuppan

2) Chinese Medicine : P. 506, 1972, Shanghai People's publishing Corp.

3 ) Nakatani, Y. : Ryodoraku autonomic nervous system treatment, P. 371, 1971, Tokyo Ryodoraku Autonomic Nercous System Research Institute.

Case A : 25-year-old female, May 1975

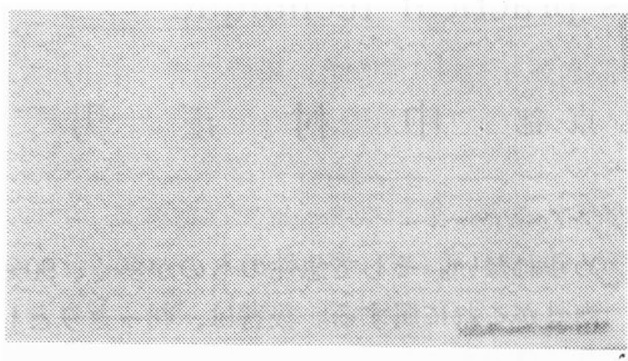

Before treatment, June 1975

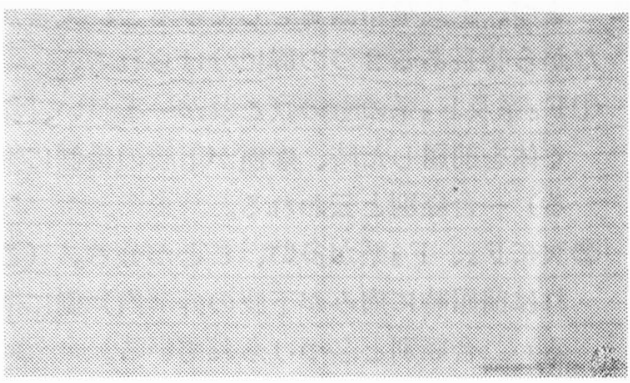

After treatment, June 1975

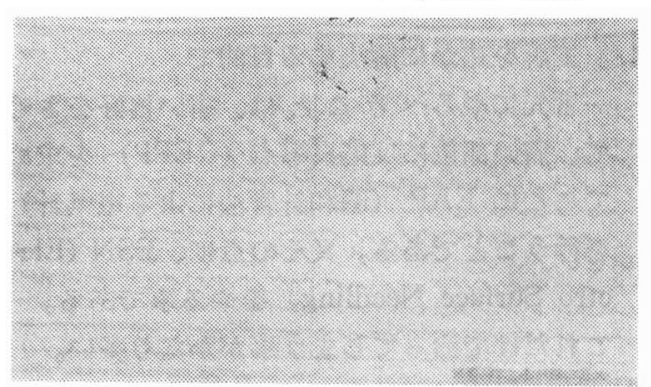

Case C : 40-year-old male, May 1970

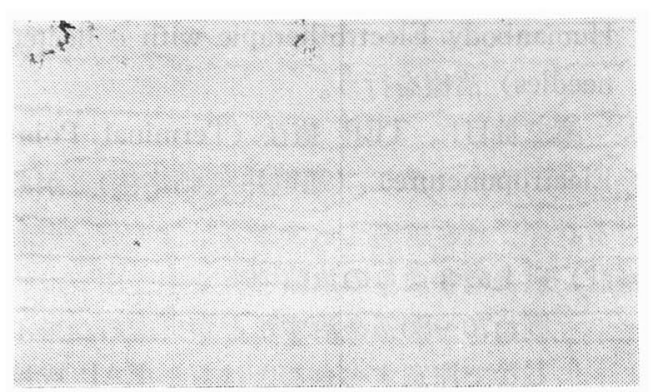

Case B : 22-year-old female, May 1975

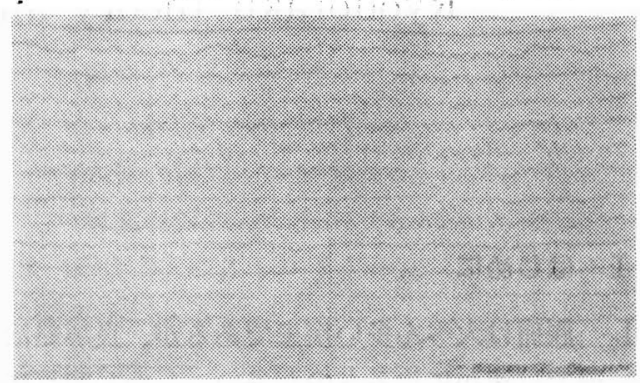

Before tratment, July 1975

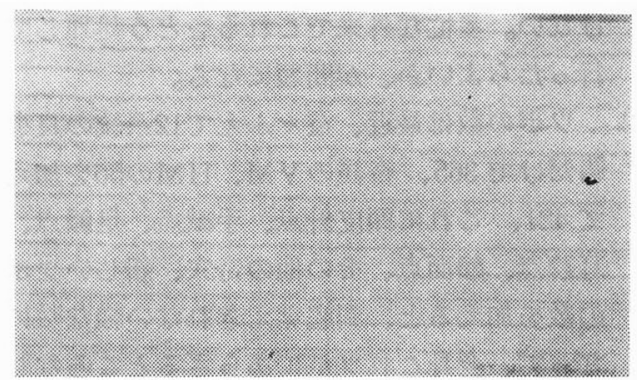

After treatment, July 1975

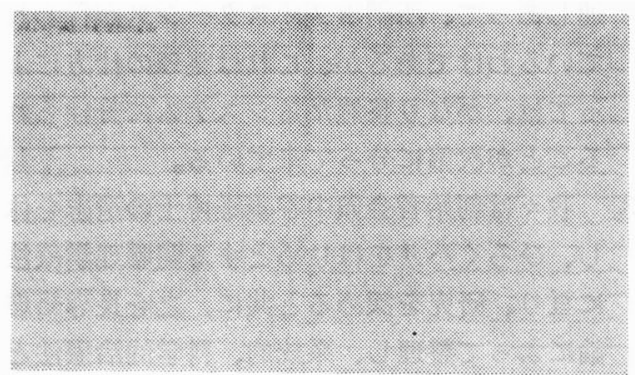

The EEG showed a complete improvement immediataly after the conset of treatment. As the patient left the hospital upon healing. He has not been examined since then, but he has been healthy for five years. 